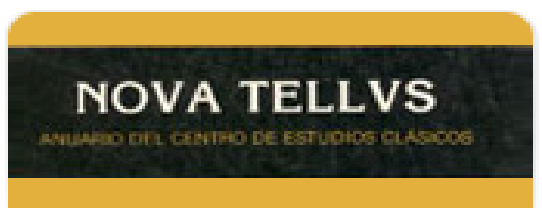

Nova Tellus

ISSN: 0185-3058

novatelu@servidor.unam.mx

Centro de Estudios Clásicos

México

García Pérez, David

Representación de las Bacantes en Cortázar y Carpentier: la relectura de un mito griego

Nova Tellus, vol. 32, núm. 2, 2015, pp. 271-287

Centro de Estudios Clásicos

Distrito Federal, México

Disponible en: http://www.redalyc.org/articulo.oa?id=59139884008

- Cómo citar el artículo

- Número completo

- Más información del artículo

- Página de la revista en redalyc.org

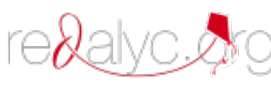

Sistema de Información Científica

Red de Revistas Científicas de América Latina, el Caribe, España y Portugal Proyecto académico sin fines de lucro, desarrollado bajo la iniciativa de acceso abierto 


\title{
Representación de las Bacantes en Cortázar y Carpentier: la relectura de un mito griego
}

Representation of the Bacchae in Cortázar and Carpentier: the Rereading of a Greek Myth

\author{
David GARCía PÉREZ \\ Universidad Nacional Autónoma de México \\ hyperion0z@yahoo.com
}

\begin{abstract}
RESUMEN: Desde la perspectiva de la literatura comparada, en este artículo se explora la relectura de la tragedia griega, específicamente del mito y del rito de las Bacantes a través del tópico de la música, en "Las Ménades", cuento de Julio Cortázar, y en El acoso, novela de Alejo Carpentier, con la finalidad de analizar las pautas de reelaboración literaria y de innovación temática en los relatos referidos.
\end{abstract}

ABSTRACT: From the perspective of comparative literature, this paper explores the reinterpretation of Greek tragedy, specifically of myth and ritual of the Bacchae through the topic of music, in "Las Ménades", a tale by Julio Cortázar, and $E l$ acoso, a novel by Alejo Carpentier, in order to analyze the patterns of literary reworking and thematic innovation in the referred literary works.

Palabras Clave: Bacantes, Carpentier, Cortázar, literatura comparada, música, tragedia griega. KeYwords: Bacchae, Carpentier, Cortázar, Comparative Literature, Music, Greek Tragedy.

RECIBIDO: 22 de febrero de 2015 - ACEPTADO: 17 de marzo de 2015.

Los antiguos mitos griegos transformados en materia literaria han hallado tierra fértil a través de su recreación de notables escritores latinoamericanos del siglo xx. De acuerdo con Claudio Guillén, "el complejo temático de una obra literaria se compone de una variedad de elementos entre los cuales existen relaciones o distancias más bien verticales, espaciales, que van de lo más visible a lo más profundo". ${ }^{1}$ Si se piensa en la complejidad de tales relaciones existentes en la remodelación de los mitos griegos que se percibe en la literatura latinoamericana del siglo pasado, cronotopo tan alejado de la fuente "original", se comprende en cierta medida la ramificación de las distintas lecturas e interpretaciones a lo largo del tiempo. La tradición clásica en la literatura es un espacio creativo, múltiple y diverso: los más variados tópicos y los temas más

\footnotetext{
${ }^{1}$ Guillén 2005, p. 272.
} 
trascendentes son objeto de una renovación de acuerdo con los intereses del hic et nunc que cada autor pergeña. Por tal razón, la persistencia de los clásicos se aprecia con notorio vigor en aquellas propuestas literarias que, sin dejar de ser originales en el sentido moderno, al mismo tiempo están atentas a la secuencia ininterrumpida de los temas y las formas de la antigüedad clásica. Paola Vianello reflexionaba, en las clases de Literatura griega que impartió en la Facultad de Filosofía y Letras de la Universidad Nacional Autónoma de México, que si los clásicos griegos y latinos tenían un futuro prometedor en cuanto materia de estudio en América Latina, ese era el de la investigación de su tradición, esto es, la búsqueda incesante del modo en que se ha leído a los clásicos y para qué, en la idea de que se trata de una de las raíces culturales, ${ }^{2}$ la más significativa, que ayuda a explicar lo que somos como latinoamericanos. Y si se otea brevemente el amplio espacio de la literatura latinoamericana del siglo Xx, los argumentos para apoyar lo dicho tanto por el estudioso español en términos de la literatura comparada, y lo sostenido por la filóloga italo-mexicana respecto de la tradición clásica son abundantes y evidentes. ${ }^{3}$

Pues bien, sirva lo anterior como preámbulo que razona el motivo central del presente análisis: establecer una serie de elementos comparativos entre dos piezas narrativas de autores consagrados de América Latina con el mito y ritual de las bacantes, las mujeres bajo el influjo catártico de Dioniso, según la descripción de Eurípides en la tragedia homónima. Se trata del cuento "Las Ménades", publicado en 1956, del argentino Julio Cortázar (1914-1984), y de la novela El acoso, que salió a la luz dos años después de éste, del cubano Alejo Carpentier (1904-1980). El motivo que permite trazar un puente entre ambas obras es que, más allá

\footnotetext{
${ }^{2}$ Vianello Tessarotto plasmó algunas reflexiones sobre este tema recién iniciaba su notable magisterio en la Facultad de Filosofía y Letras: “... conocerlos y meditar — para comprenderlos - sobre los pensamientos y las realizaciones de los hombres del pasado, y de entre ellos los griegos y los romanos, significa capacitarse para reflexionar con mayor amplitud de visión, curiosidad intelectual y sentido crítico sobre tantos aspectos de la historia que estamos materialmente viviendo. Ignorarlos significa perder elementos para comprender nuestra manera de ser, de ver el mundo y de actuar, en definitiva dentro de él” (1969, p. 650).

${ }^{3}$ Campuzano 2006, p. 9: “... en la ya muy considerable lista de importantes estudios sobre la pervivencia de los mitos clásicos en la producción cultural de la modernidad, debidos a excelentes críticos, el mundo iberoamericano continúa siendo una terra incognita".
} 
de su particular quid, apuntan hacia una reflexión sobre el teatro griego antiguo, en general, y en particular destaca la relectura del mito de las bacantes, lo que a su vez conduce a la hipótesis aristotélica sobre el origen del teatro que relaciona las fiestas dionisiacas, específicamente los ditirambos, con el nacimiento de la tragedia. ${ }^{4}$ Como se puede observar, hay un interés por meditar sobre ciertos elementos que conciernen al hecho teatral, tomando como punto de partida, mítico y temático, algunos componentes del antiguo teatro griego. El abordaje narrativo consiste en ambos casos en delinear la dramaturgia dentro de una situación de su particular contexto que, sin embargo, refiere constantemente al mundo antiguo y a la prolongación del sentido propio de la tragedia.

La obra de Julio Cortázar se caracteriza por definir en sí misma una poética, es decir, algunas premisas de teoría literaria que perfilan originales modos de creación en el ámbito de la literatura latinoamericana del siglo Xx..$^{5}$ No obstante que la narrativa es lo que distingue a este escritor, también se interesó por el teatro, y en ambos géneros se advierte un ejercicio de meta-referencialidad. En efecto, en Los Reyes (1949), tragedia poética, así definida por el propio autor, Cortázar estableció una doble vía de relectura del mito griego: el tema (el mito del Minotauro) y la forma (los componentes del teatro griego). ${ }^{6}$ Más tarde, en "Las Ménades", el argentino abordó otro mito griego que guarda también una doble relación con la tradición del teatro griego, en el que la metareferencialidad es requisito para entender la recepción del mito: por una parte, el tópico de las mujeres seguidoras de Dioniso y, por otra, la proyección de elementos teatrales a través de la música. ${ }^{7}$

${ }^{4}$ Cf. Ar., Po. 49a10-11. En Las ranas, Aristófanes delinea, en cierto modo, la tradición dionisiaca y su relación con el teatro. La presencia de Dioniso como personaje central y el juicio poético que realiza en relación con las tragedias de Esquilo y de Eurípides principalmente y, colateralmente, de Sófocles, marca la pauta para la configuración del canon de la antigua tragedia griega.

${ }^{5}$ Cf. Scholz 1977, passim.

${ }^{6}$ Cf. Curutchet 1972, pp. 13-16.

${ }^{7}$ Cortázar señaló que no tenía mayor interés en la mitología griega antigua al momento de escribir ciertas obras, como es el caso de Los Reyes y de "Las Ménades". Dicha aseveración no puede ser admitida bajo la luz de la recepción creadora que acusa el origen de sus preocupaciones temáticas. De modo inverosímil, Cortázar llegó a afirmar que el punto de arranque de la creación yace en el inconsciente que, como el sueño, hace brotar imágenes del remoto pasado. Cf. Soler Serrano 1977, entrevista grabada por RTVE. En esta conversación, además, Cortázar reconoce a Borges como maestro en los 
Y es la música precisamente otro de los vínculos que hay entre el cuento del argentino y la novela del cubano. En efecto, en $\mathrm{El}$ acoso, Carpentier acudió principalmente al tratamiento del mito de Orestes en las distintas versiones de los trágicos griegos. No obstante que este narrador apuntó que el origen de su novela se encuentra específicamente en el cruce de la Sinfonía Heroica de Beethoven ${ }^{8}$ y Las Coéforas de Esquilo, ${ }^{9}$ y que ambas obras marcan la cadencia de este breve relato, es evidente que esta segunda fuente resulta mucho más amplia, según se demostrará, pues rebasa la piezas dramáticas esquileas y abreva en el contenido general de la tragedia griega. Afirmó Carpentier que la idea de su relato germinó:

de una tragedia metida en otra tragedia. [...] Poco a poco fui pensando que podía hacerse una novela en la que el tiempo de la lectura concordara con el tiempo de la acción y el tiempo de la acción, a su vez, con la unidad de medida, con algo que por sus limitaciones de tiempo pudiera darle al lector la idea de que la acción transcurre entre tales y tales minutos. Se me ocurrió que durante una ejecución de la Sinfonía heroica en el teatro [...] podía inscribirse la tragedia, dentro de esa gran tragedia que es Las Coéforas. ${ }^{10}$

Como se puede apreciar, tanto Carpentier como Cortázar siguieron la técnica mise en abyme, es decir, crearon el efecto de insertar una serie de referentes textuales dentro del texto en cuestión, ayudándose en este caso de cierta apreciación de la música. La descripción ejecutada por estos escritores engendra un espacio de ficción "capaz de establecer relaciones significantes de concordancia o de discordancia, con el mundo real; de

primeros años de su formación literaria a la que pertenecen sus composiciones poéticas tempranas: la influencia de "La casa de Asterión" de Borges es irrecusable respecto del tema literario de Los Reyes de Cortázar. Sobre el tratamiento del mito del Minotauro en Los Reyes, cf. García Pérez 2008, pp. 205-239.

${ }^{8}$ Es la Sinfonía número 3, opus 55, compuesta entre 1802 y 1804 y enmarcada en el estilo romanticista y clasicista. La obra estaba dedicada a Napoleón Bonaparte.

${ }^{9}$ La relación entre música y narración es uno de los campos creativos cultivados por Carpentier. Además de $\mathrm{El}$ acoso, hay un tejido retórico a partir del fondo y la forma en Concierto barroco, La consagración de la primavera y Los pasos perdidos. Pero se ha señalado dentro de la misma obra de Carpentier a "Oficio de tinieblas" (1943), cuyo cotexto habría sido la Misa de Réquiem de Esteban Salas, músico cubano del siglo XVII, como antecedente directo del experimento literario-musical de El acoso. Cf. Padura Fuentes 2002, pp. 249-250. Cf. también Carpentier 2002, t. III, p. 85.

${ }^{10}$ Chao 1985, pp. 111-112. 
esta relación surge aquel 'contrato' de inteligibilidad, entre el lector y el texto narrativo, que funda la existencia misma del relato". ${ }^{11}$ En ambos casos, la sala de conciertos es el espacio de ficción en el que se lleva a cabo la representación de dos mitos griegos en el contexto de la literatura latinoamericana del siglo Xx, las Ménades y Orestes, ${ }^{12}$ mediante la cual se rompe la división imaginaria entre el público y los músicos, pues media en ellos una fuerte sujeción dada por la música, in crescendo, que rompe la barrera imaginaria que divide al escenario del lugar de los receptores. Este procedimiento creativo quizá sea común por lo menos desde la tragedia griega: Eurípides, en Las Bacantes, proyectaba ya una especie de metateatralidad en el momento en el que Dioniso, patrono del espacio teatral, asumía el papel de uno de los personajes centrales en esta tragedia. ${ }^{13} \mathrm{El}$ dios que presidía la representación teatral bajó a la orchestra para actuar su propio personaje, esto es, fue actor de su propia pasión teatral.

En lo que corresponde a El acoso, la ejecución de la Sinfonía Heroica debería de durar, bien ejecutada, cuarenta y seis minutos. Es el mismo tiempo que alcanzaría la lectura de El acoso, según el cálculo de Carpentier; ${ }^{14}$ la especificidad del tiempo irradia la desenvoltura de la acción en un recinto acotado como lo es el teatro y también el pensamiento del joven perseguido, personaje principal del relato carpenteriano, es decir, la característica del tiempo y del espacio que manifiesta el carácter abisal del relato: un cronotopo en el que la secuencia musical es compás del desenvolvimiento de las acciones contenidas en un sólo lugar, mismo que conduce a la confluencia simultánea de tópicos de diversa índole.

11 Pimentel 2001, p. 39.

${ }^{12}$ Aquí no nos ocuparemos del mito de Orestes; la atención la centramos en la relación entre música y literatura a través de la figura de la ménade presente en ambos textos. Sobre la relectura el mito de Orestes en El acoso, cf. García Pérez 2013, pp. 91-109.

${ }^{13}$ Napoli 2010, p. 61: “Bacantes constituye una inagotable cantera de procedimientos autorreferenciales sobre el teatro: la presencia de una obra dentro de otra obra, la reflexión sobre las emociones que el teatro debe producir sobre los espectadores, los casos en los que un personaje se refiere a sí mismo o a los demás como a un actor y a sus acciones como a representaciones teatrales y la referencia teatral de la escena [...] en las intervenciones que suplen las acotaciones escénicas".

${ }^{14}$ Hay que remarcar "bien ejecutada", pues la Heroica fue objeto de crítica en su momento por el hecho de romper con el tiempo utilizado para una sinfonía, pues cuarenta y cinco minutos de ejecución era una suerte de novedad. Carpentier, melómano a fin de cuentas, puntualiza el tiempo precisos de ejecución que debe coincidir con la lectura de El acoso. 
La trama es linealmente sencilla: un joven llega a la capital para estudiar arquitectura; se afilia al Partido Comunista; participa activamente en las protestas contra el sistema vigente al grado de perpetrar atentados. Sin embargo, pronto se da cuenta del juego de espejos que significa, vis-à-vis, el orden del estado al que se ataca y el sistema político que, en teoría, se pretende implantar. Ante tal circunstancia y sintiéndose burlado, el joven estudiante no duda en convertirse en delator, lo que finalmente lo conduce a la muerte. Todo lo anterior se relata en el espacio cercado por la sala de concierto y por el fluir de la conciencia del perseguido.

Por lo que corresponde a "Las Ménades", el título anuncia de manera inmediata el origen de la trama: las mujeres seguidoras de Dioniso, que como tema es ampliamente interpretativo por los diversos significados religiosos y literarios que contiene. Por ello, hay que notar que Cortázar lo acota con la determinación del juicio sobre la ejecución musical y sus efectos nocivos sobre un determinado público, esto es, la música como una enfermedad que contagia y conduce a la destrucción o a la cura de las afecciones anímicas. La reescritura que se propone tendría como motor Las Bacantes de Eurípides, título ocultamente insinuado con otra referencia que alude a un estado de locura. Pero nuestro autor no se propuso seguir a pie juntillas al poeta trágico de la antigüedad, sino que su interés fue la reedificación del tópico de la música como contrapunto irónico de una élite provinciana que representa en su contexto la alta cultura y el tópico de la locura originado en esta misma: el punto central de la locura, cualidad propia de toda ménade, a través del compás musical. ${ }^{15}$

En el cuento, la música clásica es el medio por el cual se inocula la locura. Hay que observar que se coloca esta clase de música en el mismo nivel de una hipotética melodía dionisiaca, porque induce a los oyentes a una especie de éxtasis que concluye en el sparagmós que padece el director de la orquesta a manos del provinciano auditorio, imagen que recuerda de inmediato la misma situación de Penteo en Las Bacantes de Eurípides. ${ }^{16}$

${ }^{15}$ Goyalde Palacios 2001, p. 41: "El mito interesa a Cortázar en cuanto que subvierte un orden, en la medida en que pone en cuestión la ciudad y la civilización por medio de la posesión, el éxtasis y a través de la transgresión de las normas; pues el autor, ante lo ya conocido, identifica lo dionisíaco con el <<abismo original>>”.

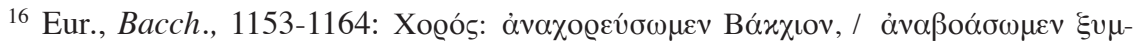

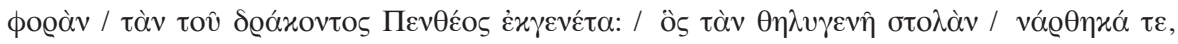

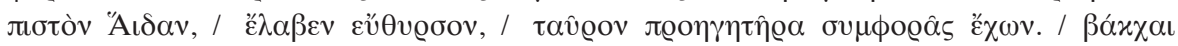

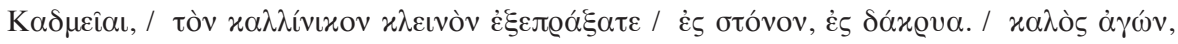

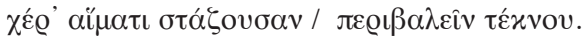


¿Acaso Cortázar quiso decir que Apolo y Dionisio se conjuntan en la locura que contagia la música? Quienes asisten a un concierto, en una pequeña localidad de cualquier país sin mayores luces, pero con muchas pretensiones intelectuales, son actores de su propia condición humana y, acusadamente, insulsa. En efecto, una de las consecuencias que se aprecian en el relato es que el individuo es, por lo menos, un ser ambivalente, porque transita de la equilibrada condición del ser civilizado, que se cultiva escuchando música clásica aunque no la comprenda, a un ser salvaje que es capaz de destrozar todo cuanto tiene enfrente y aún de provocar daño a otros seres, y todo ello a causa del deleite que provoca la música. Entre el refinamiento intelectual y la tosquedad báquica hay una frontera porosa, siempre a punto de romperse.

La música, puerta que franquea a la locura sagrada porque es punto de arranque para la catarsis, opera también como guía del relato carpenteriano. ${ }^{17}$ La música de Las Coéforas es representación de la conciencia que persigue a Orestes y que lo asedia hasta acorralarlo contra los linderos de la locura. De igual manera, el personaje central de El acoso es físicamente perseguido por dos vengadores, reflejo un tanto burdo de las Erinias esquíleas, pero la tensión del relato se torna aguda en la medida en que el lector acude a la conciencia misma del acosado y, de este modo, casi le es posible tocar los entramados del pensamiento a punto de romperse a causa del agolpamiento de múltiples padecimientos:

(... ese latido, que me abra a codazos; ese vientre en borbollones, ese corazón que se me suspende, arriba, traspasándome con una aguja fría, golpes sordos que me suben del centro y descargan en las sienes, en los brazos, en los muslos; aspiro a espasmos; no basta la boca, no basta la nariz; el aire me viene a sorbos cortos, me llena, me queda, me ahoga, para irse luego a bocanadas secas, dejándome apretado.... $)^{18}$

En lo que concierne al tema, Las Coéforas le proporcionó Carpentier su personaje/mito: Orestes, el perseguido. A este respecto queremos

${ }^{17}$ Acerca de la vinculación estructural de la música y la narración en la narrativa de Alejo Carpentier, cf. De Giacomán 1968, pp. 113-129.

18 Alejo Carpentier 2002, t. III, p. 91. El paréntesis que encierra las palabras del acosado indica el monólogo interior, la voz soterrada que sólo puede ser escuchada por el lector, pero no por los persecutores; este aspecto narrativo apenas si es mencionado por la crítica carpenteriana (cf. Padura Fuentes, op. cit., p. 342, apenas una línea) y merecería un mayor detenimiento en virtud de los espacios narrados a partir de las voces de los personajes. 
llamar la atención sobre dos configuraciones referentes al tema desarrollado en El acoso, hecho que se vincula necesariamente con la reinterpretación que Carpentier hizo del mito del hijo de Agamenón. En primer lugar, a pesar de la revelación del novelista en torno a sus fuentes de inspiración y a sus motores creativos, puede considerarse que la figura de la Erinia es capital en el ritmo narrativo de la novela, indicio señalado desde el mismo título, y, al mismo tiempo, es un tópico que determina la recepción del mito de Orestes en el universo tematológico de Carpentier. En segundo lugar, Las Coéforas como punto de partida en la creación de El acoso se explica por lo ya señalado en el primer punto y, sobre todo, porque Carpentier concibió su propuesta en el marco amplio de la tragedia griega, es decir, si bien el escritor cubano manifestó por sí mismo los orígenes temáticos y estructurales de su relato, lo cierto es que, en el plano del mito, a su novela acude la trilogía de Orestes, en su conjunto, y no sólo a Las Coéforas; además, es notoria la presencia de la Electra de Sófocles, que es literal en algunos pasajes, y la Electra y el Orestes de Eurípides concurren aportando cualidades del concepto de héroe.

Como se puede apreciar, los textos referidos son muestra de una clara recepción y reinterpretación de temas mitológicos y literarios. La asimilación del mito griego es condición necesaria para su reelaboración. De otro modo, el autor cerraría toda perspectiva de análisis, no obstante que desde los títulos se conjetura con claridad la fuente temática, dejando únicamente la posibilidad de leer, para el caso del cuento de Cortázar, siguiendo las reglas del divertimento que da el juego, pues la poética del argentino parte del supuesto de que entre el autor y el lector hay un entendimiento tácito que se hace evidente en las reglas del juego y de la lectura; ${ }^{19}$ o bien, que lo expresado por este autor sea parte del juego en tanto premisa de éste que coloca al lector en cierta lugar del proceso de lectura. En el caso de la novela de Carpentier, la asimilación de diversos mitos griegos se manifiesta en el contrapunto de la música clásica que semeja el ritmo de la persecución y la movilidad del perseguido, un traidor, todo ello, como ya se dijo, en el espacio inverosímil de una sala de concierto.

Sin dejar de lado el aspecto lúdico, innegable en la obra cortazariana, hay una serie de tópicos tomados de la literatura griega antigua que funcionan en dos planos: el primero de ellos corresponde a los elementos

${ }^{19}$ Cf. Harss 1967, pp. 62-65; Allen 1969, pp. 116-118. 
temáticos que Cortázar reelabora en "Las Ménades"; el otro plano, es propiamente el meta-teatral, que sirve para reflexionar sobre el género literario (tragedia) e, incluso para replantear algunos componentes del origen del drama. En el examen de esta pieza se aprecia el interés del escritor por jugar con el fondo y la forma, sabiendo que son dos fronteras irrecusables, pero que lo que ellas delimitan es el espacio en que se puede experimentar el quehacer literario. Vale la pena recordar que Cortázar al hablar de los escritores indicaba que "los rebeldes lo son sólo en cuanto a sus ideas sobre el contenido y las formas genéricas, nunca en cuanto al instrumento expresivo cuya latitud parecen ligeramente considerar inagotable" ${ }^{20}$ Ligeramente inagotable no puede ser más que otra expresión irónica de Cortázar al referirse a los temas literarios, pues realmente la materia del mito resulta todo lo contrario: es una fuente que no tiene fin en la reescritura literaria y prueba de ello son las piezas ya referidas del argentino, así como la novela de Carpentier.

Por otra parte, se puede observar que en El acoso hay también un juego del drama: el personaje principal de la novela se asila en el teatro en donde presencia los movimientos musicales; su pensamiento camina y se oculta junto con las notas, al lado del resto de los espectadores. Aquél y éstos son actores en el gran teatro del mundo y, a la vez, observan el drama como el artificio del escenario. Los vasos comunicantes entre escenario y anfiteatro dan pauta a la tragedia que el individuo está padeciendo. El acosado es un joven que en la Universidad se enroló en un movimiento estudiantil identificado con el comunismo. ${ }^{21}$ De una manera casi gratuita, se ve envuelto en la vorágine de las protestas y abandona sus estudios de arquitectura para convertirse en un terrorista. Al igual que Orestes, este personaje es perseguido por la conciencia, pues se convirtió en delator por interés y por miedo. Los persecutores físicamente acosan al joven, lo que concretamente se verifica en el hecho de que todo el relato transcurre en el teatro al que ha llegado el joven para ocultarse, pero al final es asesinado, a diferencia de Orestes. En este drama, la Erinia no se convirtió en Euménide:

${ }^{20}$ Cortázar 1994, p. 38.

${ }^{21}$ El trasfondo histórico de El acoso gira alrededor del año de 1933, cuando el dictador Gerardo Machado es derrocado y en su lugar gobernó Fulgencio Batista, también de manera dictatorial. 
Entonces, dos espectadores que habían permanecido en sus asientos de la penúltima fila se levantaron lentamente, atravesaron la platea desierta, cuyas luces se iban apagando, y se asomaron por sobre el barandal de un palco ya en sombras, disparando a la alfombra [...] "Uno menos", dijo el policía recién llamado, empujando el cadáver con el pie. ${ }^{22}$

La novela principia en el momento en el que el acosado irrumpe en el teatro, esto es, cuando este personaje ya ha cometido la traición y cuenta su historia, el pasado, a la vez que hilvana con ello la angustia del tiempo presente. Esta disposición de la narración coincide con el trazo dramático del Orestes de Eurípides. Ya dentro del inmueble, la descripción física y moral del acosado concuerda con la situación bajo la que Eurípides presenta a Orestes en la tragedia homónima: la enfermedad, el terror y la soledad los abrigan:

Ahora, en salvaje enfermedad, enfermo se consume el sufriente Orestes, aquí yaciendo en este lecho, y la sangre de su madre lo arroja de lado a lado envuelto en delirios. ${ }^{23}$

Esta breve descripción puede compararse con el abatimiento que experimenta el joven acosado cuando ya ha ingresado a la sala de conciertos. Al igual que Orestes, la persecución lo enferma:

(... lo que los ojos tratarán de esquivar, pasando más arriba, más abajo, para acabar de marearse; apretar los dientes, apretar los puños, aquietar el vientre - aquietar el vientre-, para detener ese correrse de las entrañas, ese quebrarse de los riñones, que me pasa el sudor al pecho; una hincada y otra; un embate y otro; ... $)^{24}$

Dicha enfermedad debe ser curada y por ello la música funciona como artesa de la catarsis en ambos relatos. La música da lugar a una determinada purificación que, se colige, en espíritus de poco entendimiento causa estragos, lo que no deja de ser un elemento lúdico, porque Cortázar a través de un apolíneo personaje, el infaltable crítico, coloca en un platillo de la balanza a Strauss, Debussy y Beethoven, y en el otro a Brahms, Mahler y Mussorsgky, en la perspectiva de que lo más común

${ }^{22}$ Carpentier 2002, t. III, p. 170.

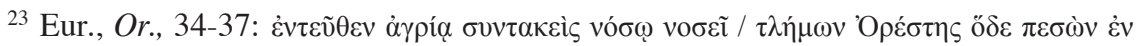

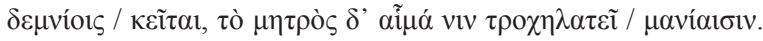

${ }^{24}$ Carpentier 2002, t. III, p. 92. 
es lo más atractivo y provocador de emociones en un público que no exige más allá de la costumbre. El fin es deslizar un juicio sobre el nivel de apreciación musical de las ménades, es decir, de todos los presentes en aquella sala de música, excepto el crítico y un hombre ciego, el Tiresias del relato cortazariano. En este cuento, las ménades no son sólo mujeres, sino también los hombres.

En el bar encontré al doctor Epifanía con su familia, y me quedé a charlar unos minutos. Las chicas estaban rojas y excitadas, me rodearon como gallinas cacareantes (hacen pensar en volátiles diversos) para decirme que Mendelssohn había estado bestial, que era una música como de terciopelo y de gasas, y que tenía un romanticismo divino. ${ }^{25}$

La figura de la ménade como tema simbólico sirve a Cortázar para desarrollar una de sus preocupaciones creativas: la labor del crítico. El cuento reelabora el significado de la ménade de manera tripartita:

a) la música es el principio catalizador de una colectividad anodina, que busca en la comunión del recinto teatral y musical la pertenencia y el reconocimiento. Si el director de la orquesta logra que las pasiones individuales comulguen con el estrépito de la Quinta Sinfonía, entonces se llega a

b) la locura; el crítico cortazariano es Apolo presente en su espacio, como convidado de piedra, en el lugar donde Dioniso ejecuta el drama: mira, escucha, aprecia el repertorio y juzga. El crítico no se centra sólo en la selección musical del maestro, sino en las opiniones y reacciones del público. Critica sobre todo a partir del pobre juicio de las ménades y su dramatismo, más que sobre la ejecución musical. Sin embargo, ambos puntos de vista sirven de marco para comprender el menadismo.

c) En efecto, la sala poco a poco se convierte es una representación en la que prácticamente todos los presentes se vuelven locos. El maestro, viendo a su orquesta, no percibe que está causando furor en el público. Una mujer en trance que avanza hacia él es el arranque para que la catarsis sea un hecho:

Casi nadie oyó el primer grito porque fue ahogado y corto, pero como la muchacha estaba justamente delante de mí, su convulsión me sorprendió y al mismo tiempo la oí gritar, entre un gran acorde de metales y maderas. Un grito seco y breve como de espasmo amoroso o de histeria. Su cabeza se dobló hacia atrás, sobre esa especie de raro unicornio de bronce que tienen

${ }^{25}$ Cortázar 2011, p. 431. 
las plateas del Corona, y al mismo tiempo sus pies golpearon furiosamente el suelo mientras las personas a su lado la sujetaban por los brazos. Arriba en la primera fila de tertulia, oí otro grito, otro golpe en el suelo. ${ }^{26}$

La descripción de la Ménade es aquí y en otras partes del cuento, semejante a la que hallamos entre los antiguos griegos: el furor menádico cambia la acción normal de la mujer que entre el baile y sus reacciones expresa el éxtasis que la lleva a la catarsis. La locura conduce a la destrucción del espacio dramático. La primera mujer, la que está vestida de rojo y que inició el trance extático, es también la encargada de marcar la pauta de destrucción del espacio escénico. El público entero, salvo el crítico y el ciego, expresa su pasión de manera violenta al punto de que el director de la orquesta es el sujeto del sparagmós, en sentido figurado, pues se trata de un furor hasta cierto punto contenido que no llega al sacrificio absoluto. Sin embargo, simbólicamente es necesario sacrificar al causante de la embriaguez musical, pues sólo de ese modo puede restaurarse el orden, tal como sucede, no sin antes remarcar cómo el ser civilizado, el que escucha música refinada, se comporta en el arrebato como una bestia sin control:

Los gritos sobrepujaban ahora los aplausos, la gente estaba demasiado ocupada abrazando y palmeando a los músicos para poder aplaudir. de modo que la calidad del estrépito iba virando a un tono cada vez más agudo, roto aquí y allá por verdaderos alaridos entre los que me pareció oír algunos con ese color especialísimo que da el sufrimiento, tanto que me pregunté si en esas carreras y en los saltos no habría tipos quebrándose los brazos y las piernas, y a mi vez me tiré de vuelta a la platea ahora que el escenario estaba vacío y los músicos en posesión de sus admiradores que los llevaban en todas direcciones, parte hacia los palcos, donde confusamente se adivinaban movimientos y revuelos, parte hacia los estrechos pasillos que lateralmente conducen al foyer. ${ }^{27}$

Las ménades del cuento cortazariano son a las Erinias de la novela carpenteriana, lo mismo que la música es a la catarsis. En efecto, si la música logra elevar a los personajes de "Las Ménades" hasta colocarlas fuera de sí y con ello purificarlas, en El acoso la persecución marcada al ritmo épico y raudo de la Sinfonía Heroica conduce al acosado a la catarsis que significa su muerte. El fluir de la conciencia del acosado es el mecanismo que proyecta al lector tanto al tiempo acotado por la música

\footnotetext{
${ }^{26}$ Ibid., 436-437.

${ }^{27}$ Ibid., 440-441.
} 
de manera inverosímil, como a las causas de la acción narrativa: entre la llegada del joven al teatro y su ejecución, el lector es testigo del acoso espiritual de este personaje. ${ }^{28}$

Así pues, las Erinias como signo de la conciencia es el elemento medular en el desenvolvimiento del monólogo interior del acosado. Para entender este supuesto, hay que delimitar el sustrato de los tópicos de la tragedia esquilea a la que acudió Carpentier: luego de asesinar a Egisto y de darse cuenta de que Clitemnestra, su madre, fue capaz de fraguar y llevar a cabo la muerte de Agamenón, sólo para satisfacer sus prohibidos placeres, Orestes mata a la reina; pero ésta le advierte antes sobre el peligro que correría al asesinarla, pues alude a las Erinias: “¡Mira! ¡Cuídate de las rencorosas perras, vengadoras de tu madre!" 29 Tales palabras se convierten en profecía maldita que cae sobre Orestes. De cualquier modo, el matricidio se consuma, pues motivos no le faltan a Orestes: "sostengo, amigos, que con justicia he matado a mi madre, esa impura asesina de mi padre, ese ser odioso para las deidades". ${ }^{30}$ A partir de ese momento, el príncipe irá a Delfos y luego a Atenas, perseguido por las

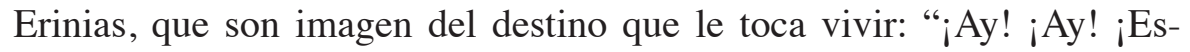
clavas, están ahí unas mujeres como Gorgonas! ¡Van vestidas de negro y enmarañadas en múltiples serpientes!"31 Esta visión de Orestes es la de su conciencia. La costumbre griega que condena los delitos de sangre deviene en el simbolismo de estos seres míticos, cuya estampa por medio de las palabras intenta representar el peso de la conciencia o el remordimiento. Que esto es así se comprende porque sólo Orestes puede ver a las Erinias. Las deidades por su propia naturaleza o los intermediarios de éstas con los hombres, como es el caso de la Pitia, también son capaces de mirar la Erinia/conciencia. La sacerdotisa de Apolo dice:

Delante de este hombre [sc. Orestes] duerme un extraño grupo de mujeres [...] No quiero decir mujeres, sino Gorgonas, pero ni a Gorgonas puedo comparar-

${ }^{28} \mathrm{Al}$ ser el contado el relato por un narrador intradiegético, los lectores son paranarratarios, pues son testigos de acciones que se producen de textos primarios - la sinfonía de Beethoven y las tragedias griegas - en el marco del acoso físico y espiritual que padece el personaje central de la novela carpenteriana.

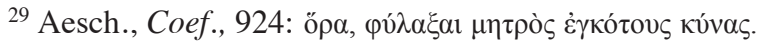

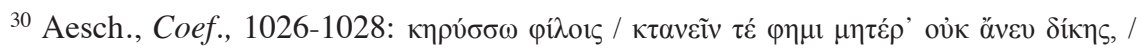

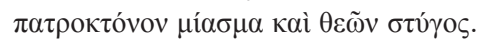

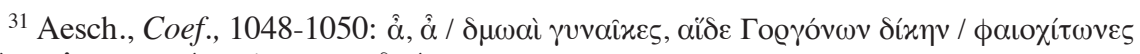

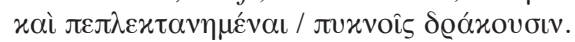


las por sus aspectos, <ni siquiera con las Harpías dotadas de alas> [...] Pero éstas se ve que carecen de alas, son de color negro y en todo repugnantes: roncan con resoplidos repelentes y de sus ojos segregan humores odiosos. ${ }^{32}$

La plasticidad con la que el poeta representa la portentosa fealdad de las diosas vengadoras es concomitante al peso de la conciencia que experimenta el héroe trágico. Esto es lo que, a mi juicio, señala la profundidad en la reinterpretación que Carpentier hizo del mito de Orestes: exponer cómo el individuo es perseguido internamente por sus propios escrúpulos, por sus culpas (reales o aparentes) que, al ahondarse, lo conducen a la muerte. Si Carpentier cita literalmente dos veces a Sófocles o si afirma que se inspiró en Las Coéforas, se distinguen, entonces, los componentes visibles en la recreación del tema. ${ }^{33}$ Sin embargo, lo trascendente es el giro temático que le imprime al mito y no el entramado metatextual que puede devenir en una función meramente retórica y narrativa.

La disposición de las tres partes en que se divide El acoso responde de manera análoga al planteamiento trágico-narrativo de Las Euménides: ${ }^{34}$

1. El acosado y Orestes, ambos perseguidos y suplicantes, se asilan el primero en el teatro y el segundo en el templo de Apolo en Delfos. El espacio funciona como catalizador del fluir de la conciencia en ambos casos. Además de este paralelismo, cabe también otro semejante entre la novela carpenteriana y el Orestes de Eurípides: el tópico del escondite, pues ambos personajes se ocultan en casa de sus respectivas nodrizas después de cometido su crimen e, incluso, la descripción de su decadente apariencia física concuerda, el acosado siente la boca terrosa, mientras que Orestes tiene grumos de espuma. ${ }^{35}$

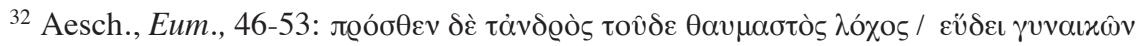

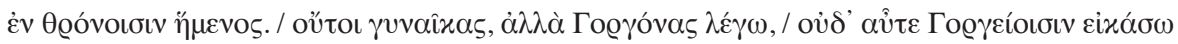

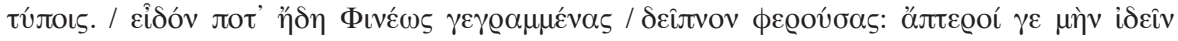

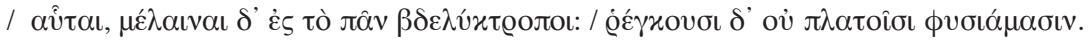

${ }^{33}$ Las partes citadas de modo peculiar son Soph., El., 1417-1420 y 1432-1435. Cf. López Calahorro 2006, pp. 83-84.

34 Disentimos de la exégesis de Losada 1999, p. 122, para quien la Electra de Sófocles representa una correspondencia con la novela de Carpentier "en alto grado de fidelidad".

${ }^{35}$ Sobre esto llamó la atención Carlos 1970, passim. 
2. Como ya se señalaba, los dos perseguidores del terrorista en $E l$ acoso son las correspondientes Erinias que, azuzadas por Clitemnestra persiguen a Orestes. La angustia del joven traidor reverbera en la frase hoc erat in votis ("este era mi deseo") como símbolo de su destino. ${ }^{36}$ Esta sentencia, tomada de Horacio, ${ }^{37}$ es un puente palmario que une la tradición clásica con la judeo-cristiana: la Erinia/conciencia ya no representa únicamente los síntomas de la enfermedad trágica, de acuerdo con la visión del teatro griego, sino que en el relato del cubano adquiere fuertes matices de tortura espiritual, nacidos en la idea del pecado y del castigo. El acosado pretende justificar su proceder aludiendo al lugar común de que las circunstancias lo condujeron a delatar, actitud que corresponde irónicamente con la imagen del católico arrepentido. En efecto, lo que para el griego era la anánke, motor que impele a los hombres a actuar y, por lo tanto, a continuar su destino y toparse indefectiblemente con la tragedia, para la novela de Carpentier es la Divina Providencia, elemento pasivo y compasivo, que metafóricamente es culpable de lo que le sucede a todo ser humano.

3. El Tribunal bajo el que es juzgado el acosado se correspondería con el Areópago, cuya fundación mítico-literaria se marca en la tragedia de Esquilo, cuando Orestes es juzgado en el templo de Atenea. La diferencia notable es que el acosado resulta condenado, no tanto por la ley en sí, sino por el martirio de los pensamientos que acosan al joven, quien, también a diferencia de Orestes, halla tranquilidad en la muerte.

Como se puede observar, los contextos construidos por Cortázar y Carpentier oscilan entre lo que se acepta y lo que se niega, entre el deleite de la música y la locura que produce, en fin, entre Apolo y Dioniso. La música es el fondo que acompaña a las Ménades y al acosado en la consecución de su destino; éste es la catarsis que libera ya sea porque cuando enloquece el público hay una verdadera presencia del yo soterrado por las reglas aceptadas civilizadamente, ya sea porque la muerte es el triunfo de la Erinia que acomete la conciencia hasta hacerla tan evidente que resulta insoportable. Cortázar mismo funge como Apolo, el crítico musical acerbo que en la ficción se imagina que observa cómo

\footnotetext{
${ }^{36}$ Carpentier 2002, t. III, p. 95. Cf. Moceaga-González 1980, passim. Llama la atención que en el primer capítulo de este volumen, "La simbología religiosa en El acoso de Alejo Carpentier", la autora no haga referencia a este pasaje de la novela en la que se aprecia con claridad un sentido religioso profundo en torno a la idea de arrepentimiento.

${ }^{37}$ Serm. 2, 6, 1: "Hoc erat in votis, modus agri non ita magnus".
} 
en un concierto de música clásica, la más refinada de acuerdo con los cánones de la pretensión intelectual, el público se deleita y enloquece con los lugares comunes de ésta. Carpentier hila un problema políticojudicial, como en la Orestiada, al transpolar la persecución de la Erinia contra Orestes en un sistema que oscila entre tiranía y democracia, y en el traidor que, llegado el punto, muere sin que se restablezca el orden perdido por causas ideológicas. ${ }^{38}$

Así pues, tanto "Las Ménades" como El acoso son relatos que muestran el grado de recepción que Cortázar y Carpentier tenían del mundo clásico grecolatino. El modo de entreverar los contenidos y la estructura es prueba también del pleno dominio de ambos escritores para crear motivos metatextuales e intratextuales. Estos ejercicios narrativos son prueba, además, de la pervivencia de los temas y motivos clásicos en la literatura de todos los tiempos. Para decirlo con Claudio Guillén: "Los motivos se dan, se hallan o se inventan; y sin ellos es difícil acceder al drama o a la novela. El tema es el destino ineluctable del escritor. Es lo que nos lleva a un tratamiento valorativo más profundo. Pero por ser común a las distintas obras de un mismo escritor ha de pensarse que el tema no está en la obra, o se descubre sólo genéticamente". ${ }^{39}$

\section{BIBLIOGRAFÍA}

Allen, Richard F., “Temas y técnicas literarias de Julio Cortázar", The South Central Bulletin, 29-4, 1969, pp. 116-118.

ARISTÓTELES, Poética, edición trilingüe, introducción y notas de Martín García Yebra, Madrid, Gredos, 1999.

Campuzano, Luisa, "Presentación", véase López Calahorro.

Carlos, A., "El anti-héroe en El acoso", en H. Giacomán, Homenaje a Alejo Carpentier: variaciones interpretativas en torno a su obra, New York, Las Américas Publishing Co., 1970.

CARPEnTIER, Alejo, Obras completas. El acoso, t. III, México, Siglo XXI, 2002.

Chao, Ramón, Palabras en el tiempo de Alejo Carpentier, La Habana, Arte y Literatura, 1985.

Cortázar, Julio, “Caballo de Troya”, en Obra Crítica 1, México, Alfaguara, 1994.

-, Cuentos completos 1, México, Santillana, 2011.

Curutchet, Juan Carlos, Julio Cortázar o la crítica de la razón pragmática, Madrid, Editora Nacional, 1972.

${ }^{38}$ Cf. el comentario de Dorfman 1970, passim.

${ }^{39}$ Claudio Guillén 2005, p. 275. 
Dorfman, Ariel, "El sentido de la historia en Alejo Carpentier", en A. V., Imaginación y violencia en América Latina, Santiago de Chile, Editorial Universitaria, 1970 .

Esquilo, Tragedias: Coéforos, Euménides, t. IV, introducción y texto revisado de Francisco Rodríguez Adrados, traducción de Esteban Calderón Dorda, Madrid, Consejo Superior de Investigaciones Científicas, 2009.

EURÍPIDES, Tragedias: Electra, Orestes, t. IV, introducción, texto griego revisado y traducción de Antonio Guzmán Guerra, Madrid, Consejo Superior de Investigaciones Científicas, 2000.

GARCíA PÉREZ, David, "Reverberaciones grecolatinas del mito del Minotauro en Jorge Luis Borges y en Julio Cortázar", Nova Tellus, 26-1, 2008, pp. 205-239.

- Los retornos de Electra y de Orestes. Metamorfosis literaria de los personajes trágicos en la literatura hispanoamericana del siglo XX. Supplementum VI de Noua tellus, México, Universidad Nacional Autónoma de México, 2013.

Giacomán, Helmy F. de, "La relación músico-literaria entre la tercera sinfonía, Heroica, de Beethoven y la novela El acoso de Alejo Carpentier", Cuadernos Americanos, 3, 1968, pp. 113-129.

Goyalde Palacios, Patricio, “'Las Ménades' de Julio Cortázar: mito clásico y recreación literaria", Faventia, 32, 2, 2001, pp. 35-42.

Guillén, Claudio, Entre lo uno y lo diverso. Introducción a la literatura comparada (ayer y hoy), Barcelona, Tusquets, 2005.

HARss, Luis, "Cortázar o la cachetada metafísica”, Mundo Nuevo, 7, 1967, pp. 57-74.

López CAlahorro, Inmaculada, Alejo Carpentier y el mundo clásico, Granada, Ediciones Universidad de Granada, 2006.

LosAdA, M., "Traslación semántica de una estructura ausente (El acoso)", en M. C. Álvarez y R. M. Iglesias, Contemporaneidad de los clásicos en el umbral del Tercer Milenio, Murcia, Universidad de Murcia, 1999.

Moceaga-GonzÁlez, Esther P., Alejo Carpentier: estudios sobre su narrativa, Madrid, Playor, 1980.

NAPOLI, Juan Tobías, "Espectáculo y teatralidad en Bacantes de Eurípides", Humanitas, 62, 2010, pp. 57-81.

Padura Fuentes, Leonardo, Un camino de medio siglo: Alejo Carpentier y la narrativa de lo real maravilloso, México, FCE, 2002.

Pimentel, Luz Aurora, El espacio de la ficción, México, Universidad Nacional Autónoma de México / Siglo XXI, 2001.

Scholz, Lázló, El arte poética de Julio Cortázar, Buenos Aires, Ediciones Castañeda, 1977.

Sófocles, Tragedias: Antígona, Electra, t. II, edición y traducción de Ignacio Errandonea, Madrid, Consejo Superior de Investigaciones Científicas, 1991.

Soler Serrano, Joaquín, A fondo. Julio Cortázar, Madrid, RTVE, 1977. Entrevista grabada por RTVE.

Vianello, Paola, "Estudios clásicos y mundo moderno”, Comunidad, IV, 21, 1969, pp. 649-655. 
